\title{
Rasio Otot-Tulang Pectoralis Berbagai Jenis Itik Lokal di Jawa Tengah
}

\author{
Ajeng Fatria Savitri, Enny Yusuf Wachidah Yuniwarti dan Sri Isdadiyanto \\ Laboratorium Biologi Struktur dan Fungsi Hewan, Departemen Biologi, Fakultas Sains dan Matematika, \\ Universitas Diponegoro J1. Prof. H. Sudharto, Tembalang, Semarang. \\ Email: fatria.as@gmail.com, enny_yusuf@yahoo.co.id, isdadiyanto@yahoo.com
}

\begin{abstract}
Local ducks farm businesses potentially developed as the meat producer, which was expected to fit and complete the nutrition for society. The provision of excellent meat quality was one of the main goals that integrated with the development of animal husbandary. The quality and quantity of meat on the carcass could be seen as one of the indicators of ducks productivity. The study about the influence of various types of ducks to pectoralis meat bone ratio as the component of commercial carcass had to be done to find out about the quality and genetics potentials of every ducks type in order to improve the quality of food. This study aimed to analyze the influence of various types of ducks in Central Java, such as Pengging duck, Tegal duck, and Magelang duck to the carcass quality evaluated from the value of pectoralis meat bone ratio. The ducks used in the study were 6 months. The types of ducks were used as comparison. Samples were taken from the three types of local ducks and the repetition was done six times for each type of ducks. The measured variables were live weight, pectoralis weight, pectoralis percentage, meat bone percentage, and meat bone ratio. The data were analyzed using ANOVA. Real different datas were analyzed by further testing Least Significant Difference Test (LSDT) at the level of 95\%. The results showed that various types of local ducks did not significantly affect the value of the pectoralis meat bone ratio, therefore it could be concluded that various local ducks did not affect on pectoralis meat bone ratio.
\end{abstract}

Keywords: Local ducks in Central Java, carcass, pectoralis meat bone ratio.

\begin{abstract}
Abstrak
Usaha peternakan itik lokal berpotensi untuk dikembangkan sebagai penghasil daging yang diharapkan mampu memenuhi dan melengkapi asupan gizi bagi masyarakat. Penyediaan daging yang berkualitas prima merupakan salah satu tujuan utama yang berintegrasi dengan pembangunan peternakan. Kualitas dan kuantitas daging pada karkas dapat dinilai sebagai salah satu indikator produktivitas itik. Penelitian mengenai pengaruh perbedaan jenis itik terhadap rasio otot-tulang pectoralis sebagai komponen karkas komersil penting dilakukan untuk mengetahui kualitas dan potensi genetik setiap itik dalam upaya peningkatan mutu pangan. Penelitian ini bertujuan untuk menganalisis pengaruh perbedaan jenis itik lokal Jawa Tengah, yakni itik Pengging, itik Tegal dan itik Magelang terhadap kualitas karkas ditinjau dari nilai rasio otot-tulang pectoralis. Itik yang digunakan dalam penelitian ini berumur 6 bulan. Jenis itik digunakan sebagai pembeda. Sampel diambil dari ketiga jenis itik lokal dan dilakukan pengulangan sebanyak 6 kali dari setiap jenis itik. Variabel yang diukur antara lain bobot hidup, bobot pectoralis, persentase pectoralis, persentase daging dan tulang, serta rasio otot-tulang pectoralis. Data dianalisis menggunakan analisis variansi (ANOVA). Data yang berbeda nyata dianalisis dengan uji lanjut Least Significant Difference Test (LSDT) pada taraf kepercayaan 95\%. Hasil penelitian menunjukkan bahwa perbedaan jenis itik lokal tidak berpengaruh nyata terhadap nilai rasio otot-tulang pectoralis, sehingga dapat disimpulkan bahwa perbedaan itik lokal tidak berpengaruh terhadap rasio otot-tulang pectoralis.
\end{abstract}

Kata kunci: Itik lokal Jawa Tengah, karkas, rasio otot-tulang pectoralis.

\section{PENDAHULUAN}

Usaha peternakan itik lokal di Indonesia memberikan potensi yang cukup baik untuk dikembangkan sebagai penghasil daging. Ternak itik sebagai penyedia daging dan telur kian dipopulerkan sebagai komplementer bagi ternak ayam dan diharapkan mampu memenuhi kebutuhan gizi dan kebutuhan daging nasional (Randa dkk., 2002). Itik yang dipelihara untuk tujuan produksi daging dapat diperoleh dari 
peternakan itik potong atau itik pedaging, itik petelur yang telah diafkir, itik serati, dan itik jantan yang berasal dari penetasan (Windharyati, 2002).

Produksi daging ternak unggas lokal secara langsung dapat dilihat dari bobot, persentase karkas dan banyaknya proporsi bagian karkas yang bernilai tinggi (Damayanti, 2003). Karkas terdiri dari komponennya yaitu otot, tulang, lemak dan kulit. Komponen karkas yang paling mahal adalah bagian otot. Otot merupakan bagian utama yang penting sebagai sumber daging, sebab kualitas karkas ditentukan oleh jumlah daging yang terdapat pada karkas. Otot pada bagian pectoralis, paha dan sayap, merupakan otot yang dominan pada karkas, sehingga besarnya komponen tersebut dijadikan ukuran untuk membandingkan kualitas daging pada unggas (Yuwanta, 2004). Armissaputri dkk. (2013), menyatakan bahwa otot yang ada pada bagian pectoralis dapat digunakan untuk menilai penyebaran otot pada tubuh lainnya.

Besarnya proporsi otot atau daging terhadap tulang dapat ditentukan melalui nilai rasio otottulang. Rasio otot-tulang atau Meat Bone Ratio (MBR) adalah perbandingan antara berat daging dan berat tulang. Rasio otot-tulang ini diperoleh dari pemisahan tulang dengan daging kemudian dilakukan perbandingan diantara keduanya. Ningsih (2004), menyatakan bahwa tulang dapat mencerminkan produksi otot suatu ternak dan diharapkan mempunyai proporsi yang sekecil mungkin.

Perbedaan karakteristik itik lokal Jawa Tengah yang diwakili oleh itik Pengging, itik Tegal dan itik Magelang ini menjadi hal yang melatarbelakangi untuk melakukan pengamatan lebih lanjut mengenai adanya perbedaan rasio otottulang pectoralis pada ketiga jenis itik tersebut.

\section{BAHAN DAN METODE}

\section{Waktu dan Tempat}

Penelitian dilakukan pada bulan September 2014. Pengamatan rasio otot-tulang pectoralis itik Pengging, itik Tegal dan itik Magelang dilakukan di Laboratorium Biologi Struktur dan Fisiologi Hewan, UNDIP Semarang.

\section{Bahan dan Alat}

Alat dan bahan yang digunakan antara lain: scalpel, gunting bedah dan cutter untuk membedah dan memisahkan antara bagian otot dan tulang itik, nampan plastik sebagai wadah itik, serta neraca analitik dengan kepekaan $0,1 \mathrm{~g}$ untuk menimbang bobot tubuh, bobot bagian karkas, tulang dan otot itik. Itik Pengging, itik Tegal dan itik Magelang umur 6 bulan, koran sebagai alas saat membedah itik, alat tulis serta label untuk menandai itik.

\section{Cara Kerja}

Setiap itik ditimbang dengan menggunakan neraca analitik dengan kepekaan $0,1 \mathrm{~g}$ untuk ditentukan bobot tubuhnya. Semua itik didecapitasi dengan memotong bagian arteri carotis, vena jugularis, trachea dan oesophagus (Standar Nasional Indonesia, 2009), kemudian dilakukan pembedahan di bagian abdomen hingga thorax itik dengan menggunakan peralatan bedah. Bagian pectoralis diambil kemudian ditimbang untuk mengetahui bobot pectoralis. Tulang dan otot pectoralis dipisahkan, setelah itu masingmasing komponen ditimbang.

Prosedur Pengukuran Variabel

a. Bobot hidup

Bobot hidup itik Pengging, Tegal dan Magelang ditentukan menggunakan neraca analitik dengan kepekaan 0,1 g.

b. Bobot bagian karkas

Bagian karkas yang digunakan adalah pectoralis. Pectoralis ditimbang menggunakan neraca analitik dengan kepekaan $0,1 \mathrm{~g}$ untuk menentukan bobot total pectoralis.

c. Persentase bagian karkas

Persentase bagian karkas didapatkan dengan cara membagi bobot bagian karkas dengan bobot hidup kemudian dikalikan 100\% (Armissaputri dkk., 2013).

d. Persentase otot dan tulang

Persentase otot dan tulang didapatkan dengan cara membagi otot atau tulang dengan bobot bagian karkas kemudian dikalikan $100 \%$.

e. Rasio otot-tulang (meat bone ratio) 
Rasio otot-tulang (meat bone ratio) didapatkan dengan cara membagi bobot otot atau daging dengan bobot tulang (Reksohadiprojo, 1995).

\section{Parameter Penelitian}

Parameter yang diamati yaitu rasio otottulang pectoralis.

\section{Desain Penelitian}

Desain penelitian yang digunakan adalah tiga perlakuan dan enam ulangan.

\section{Analisis Data}

Data yang diperoleh dianalisis dengan uji ANOVA, jika ada pengaruh berbeda nyata maka dilakukan uji LSD dengan taraf kepercayaan $95 \%$.

\section{HASIL DAN PEMBAHASAN}

Hasil analisis rasio otot-tulang pectoralis dari masing-masing itik lokal Jawa Tengah, yaitu itik Pengging, itik Tegal dan itik Magelang secara berurutan disajikan pada Tabel 1 .

Tabel 1. Hasil analisis rasio otot-tulang pectoralis dari ketiga itik lokal.

\begin{tabular}{cccc}
\hline \multirow{2}{*}{ Variabel } & \multicolumn{3}{c}{ Perlakuan } \\
\cline { 2 - 4 } & P1 & P2 & P3 \\
\hline
\end{tabular}

Rasio otot-

tulang $\quad 5,74 \pm 1,23^{\mathrm{a}} \quad 5,18 \pm 1,32^{\mathrm{a}} \quad 5,85 \pm 0,89^{\mathrm{a}}$

pectoralis

Keterangan: Angka dengan superskrip yang sama menunjukkan hasil yang tidak berbeda nyata $(\mathrm{P}>0,05)$.

Hasil analisis menunjukkan bahwa perbedaan itik lokal tidak berpengaruh nyata $(\mathrm{P}>0,05)$ terhadap rasio otot-tulang pectoralis. Nilai rataan rasio otot-tulang pectoralis itik dalam penelitian ini berada dalam kisaran 5,183 $\pm 1,329$ $5,854 \pm 0,899$. Nilai rataan tertinggi ditunjukkan oleh P3 dengan nilai 5,854 $\pm 0,899$, kemudian diikuti oleh $\mathrm{P} 1$ dan $\mathrm{P} 2$ dengan nilai masing-masing $5,744 \pm 1,233$ dan $5,183 \pm 1,329$. Tidak berbedanya rasio otot-tulang pectoralis pada ketiga itik lokal tersebut dikarenakan jumlah pemberian ransum relatif sama per harinya yakni 160 g/ekor untuk itik Pengging dan itik Tegal serta 170 g/ekor untuk itik Magelang. Semua itik yang digunakan dalam penelitian berumur 6 bulan, sehingga bobot dan ukuran tubuh itik relatif sama.

Tinggi rendahnya nilai rasio otot-tulang dapat ditentukan melalui berat otot pada karkas, jika berat otot lebih besar dibandingkan berat tulangnya maka dapat dikatakan bahwa nilai rasio otot-tulang pada karkas unggas tersebut tinggi. Widodo (2005), menyatakan bahwa rasio otot dan tulang dipengaruhi oleh dua komponen, yaitu bobot otot dan bobot tulang karkas. Hal ini sesuai dengan pernyataan Amaludin dkk. (2013), bahwa rasio otot tulang karkas dipengaruhi oleh bobot karkas, semakin tinggi nilai perbandingan otottulang pada karkas, maka semakin tinggi pula kualitas karkas.

Armissaputri dkk. (2013), menyatakan bahwa otot pada bagian pectoralis dapat digunakan untuk menilai penyebaran otot pada bagian tubuh lainnya. Perkembangan bagian karkas ini banyak dipengaruhi oleh protein pakan dan jenis kelamin. Persentase bobot pectoralis akan bertambah seiring bertambahnya bobot tubuh dan bobot karkas. Bobot hidup merupakan faktor utama yang menyebabkan perbedaan pertumbuhan pada otot pectoralis. Otot pada bagian pectoralis mengalami perkembangan yang lebih lebih lambat dibandingkan dengan otot pada bagian tubuh lainnya pada usia muda dan baru mulai berkembang maksimal pada usia 3-5 bulan.

Amaludin dkk. (2013), menyatakan bahwa pectoralis itik memiliki pertumbuhan heterogenik yang secara alamiah disebabkan oleh faktor genetik, jika terjadi penurunan bobot atau persentase pectoralis maka kecepatan penurunan bobot pectoralis akan lebih tinggi dari bobot bagian karkas lainnya, sehingga semakin kecil bobot karkas maka akan semakin kecil pula persentase pectoralis.

Hasil analisis bobot hidup dan bobot pectoralis dari ketiga itik lokal tercantum pada Tabel 2.

Tabel 2. Hasil analisis bobot hidup dan bobot pectoralis dari ketiga itik lokal. 


\begin{tabular}{lccc}
\hline \multirow{2}{*}{ Variabel } & \multicolumn{3}{c}{ Perlakuan } \\
\cline { 2 - 4 } & $\mathrm{P} 1$ & $\mathrm{P} 2$ & $\mathrm{P} 3$ \\
\hline $\begin{array}{l}\text { Bobot } \\
\text { hidup (g) }\end{array}$ & $1530 \pm 213,9^{\mathrm{a}}$ & $1480 \pm 115,0^{\mathrm{a}}$ & $\begin{array}{c}1491,6 \pm 126 \\
,^{\mathrm{a}}\end{array}$ \\
$\begin{array}{l}\text { Bobot } \\
\text { pectoralis } \\
\text { (g) }\end{array}$ & $165 \pm 22,5^{\mathrm{a}}$ & $161.66 \pm 14,7^{\mathrm{a}}$ & $165 \pm 17,6^{\mathrm{a}}$ \\
\end{tabular}

Keterangan: Angka dengan superskrip yang sama menunjukkan hasil yang tidak berbeda nyata $(\mathrm{P}>0,05)$.

Rataan bobot hidup dari ketiga jenis itik lokal secara berurutan dari yang tertinggi hingga terendah yakni itik Pengging (P1) sebesar $1.530 \pm 213,915 \mathrm{~g}$, disusul oleh itik Magelang (P3) sebesar 1.491,6 $\pm 126,872 \mathrm{~g}$, kemudian itik Tegal (P2) sebesar $1.480 \pm 115,065$ g. Bobot bagian karkas pectoralis itik Pengging dengan itik Magelang memperlihatkan nilai yang sama, yakni sebesar $165 \mathrm{~g}$, sedangkan itik Tegal memiliki bobot pectoralis sebesar 161,66 g. Perbedaan jenis itik lokal tidak berpengaruh nyata $(\mathrm{P}>0,05)$ terhadap kedua variabel tersebut.

Bobot karkas akan meningkat sejalan dengan bertambahnya bobot hidup itik. Peningkatan bobot hidup berkaitan dengan efektivitas metabolisme itik dalam mencerna pakan dan mengkonversikannya menjadi otot.

Buwono (2007), menyatakan bahwa bobot tubuh ternak itik dipengaruhi oleh kualitas dan kuantitas pakan yang dikonsumsi, dengan demikian perbedaan kandungan nutrisi pada pakan dan banyaknya pakan yang dikonsumsi akan memberikan pengaruh terhadap pertambahan bobot tubuh yang dihasilkan karena kandungan nutrisi yang seimbang dan cukup sesuai dengan kebutuhan sangat diperlukan untuk pertumbuhan yang optimal.

Haroen (2003), menyatakan bahwa pencapaian komponen bobot tubuh sangat berkaitan dengan bobot karkas. Persentase karkas dipengaruhi oleh faktor kualitas ransum dan laju pertumbuhan ternak. Laju pertumbuhan yang ditunjukkan dengan adanya pertambahan bobot tubuh akan mempengaruhi bobot potong yang dihasilkan, sedangkan bobot potong akan berpengaruh terhadap persentase karkas yang dihasilkan.

Persentase pectoralis, persentase tulang dan otot pectoralis dari ketiga itik lokal dapat dilihat pada Tabel 3.

Tabel 3. Persentase pectoralis, persentase tulang dan otot pectoralis dari ketiga jenis itik lokal.

\begin{tabular}{lccc}
\hline \multirow{2}{*}{ Variabel } & \multicolumn{3}{c}{ Perlakuan } \\
\cline { 2 - 3 } & $\mathrm{P} 1$ & $\mathrm{P} 2$ & $\mathrm{P} 3$ \\
\hline $\begin{array}{l}\text { Persentase } \\
\text { pectoralis (\%) }\end{array}$ & 10,78 & 10,87 & 11,06 \\
$\begin{array}{l}\text { Persentase tulang } \\
\text { pectoralis (\%) }\end{array}$ & 15,02 & 16,64 & 14,63 \\
$\begin{array}{l}\text { Persentase otot } \\
\text { pectoralis (\%) }\end{array}$ & 84,97 & 83,35 & 85 \\
\hline
\end{tabular}

Persentase bagian pectoralis pada masingmasing perlakuan berkisar antara $10,78 \%$ $11,06 \%$ (Tabel 3.). Persentase komponen karkas dari setiap perlakuan relatif sama, hal ini menunjukkan bahwa berat komponen karkas ditunjang oleh berat karkas dan bobot tubuh itik sebagai cerminan bahwa proses pembentukan protein berjalan dengan baik.

Simamora (2011), menyatakan bahwa pada periode pertumbuhan diperlukan pakan dengan kandungan nutrisi yang seimbang. Kandungan nutrisi yang menentukan performa pada unggas adalah imbangan protein dan energi, serta terpenuhinya kebutuhan vitamin dan mineral. Protein merupakan unsur utama yang diperlukan untuk pertumbuhan. Gultom dkk. (2014), menyatakan bahwa konsumsi protein yang tinggi akan mempengaruhi tercukupinya asupan asamasam amino di dalam tubuh ternak sehingga metabolisme sel-sel dalam tubuh berlangsung secara normal.

Hasil penelitian Armissaputri dkk. (2013) mengenai bobot dan persentase bagian-bagian karkas itik menunjukkan bahwa itik Magelang dan itik Tegal yang berumur 10 minggu memiliki bobot pectoralis sebesar 179,58 g dan 174,54 g, sedangkan persentasenya masing-masing yakni $12,90 \%$ dan $13,95 \%$. Penelitian tersebut menyatakan bahwa perlakuan bangsa itik lokal 
tidak berpengaruh nyata terhadap bobot dan persentase pectoralis. Bobot dan persentase bagian karkas yang didapat pada penelitian ini lebih kecil dari hasil yang didapat pada penelitian sebelumnya, nilai yang diperoleh berada pada kisaran 161,66-165 g dengan persentase 10,78\%$11,06 \%$. Hal ini diduga karena kecepatan pertumbuhan tulang dan otot yang berkaitan dengan bobot dan persentase karkas juga dipengaruhi oleh umur. Seperti yang dilaporkan oleh Suryanto (1989), bahwa peningkatan umur menyebabkan terjadinya kenaikan meat bone ratio secara nyata $(\mathrm{P}>0,05)$. Hal ini disebabkan karena kecepatan pertumbuhan tulang mengalami kenaikan yang pesat pada umur $4-12$ minggu, sedangkan umur 12-20 minggu pertumbuhan tulang akan mengalami kemunduran. Soeparno (2005) juga menyatakan bahwa perkembangan otot terhambat karena terbatasnya ukuran serabut otot pada umur yang berbeda.

Persentase otot dan tulang terhadap bobot pectoralis pada Tabel 3. menunjukkan bahwa persentase otot pectoralis berada dalam kisaran $83,35 \%-85 \%$ dengan persentase tulang yang berada dalam kisaran $14,63 \%-16,64 \%$. Persentase otot dan tulang pada bagian pectoralis ketiga jenis itik lokal yang relatif sama dapat disebabkan karena persentase bobot karkas terhadap bobot hidup itik juga tidak berbeda nyata. Samsudin dkk. (2012), menyatakan bahwa bobot karkas mempengaruhi rasio otot tulang karkas, semakin tinggi nilai perbandingannya maka proporsi bagian karkas yang dapat dikonsumsi semakin tinggi, dengan demikian semakin tinggi pula kualitas karkas. Kisaran persentase tulang bervariasi, antara $17 \%$ hingga $25 \%$.

Pembentukan otot karkas yang tinggi akan diikuti oleh penurunan atau melambatnya pembentukan tulang. Pertumbuhan dan jaringan tulang dipengaruhi oleh genetik, pakan, laju pertumbuhan dan bentuk akhir tulang. Umumnya, persentase otot yang rendah akan diikuti dengan kenaikan persentase tulang yang tinggi seperti pada itik Tegal yang memperlihatkan persentase otot sebesar $83,35 \%$ diikuti dengan tingginya persentase tulang sebesar 16,64\%. Sebaliknya, persentase otot yang tinggi akan diikuti dengan penurunan persentase tulang seperti pada itik Magelang yang memperlihatkan persentase otot dan tulang sebesar $85 \%$ dan $14,63 \%$. Arellano et al. (2004), menyatakan bahwa kandungan kalsium yang tinggi sangat membantu pertumbuhan serta kekuatan tulang. Sehingga dapat disimpulkan bahwa adanya kenaikan persentase tulang dapat disebabkan karena pertumbuhan tulang yang cepat sebagai representasi dari penyerapan kalsium dan nutrisi lain secara baik oleh tulang, namun hal ini tidak disertai dengan pertumbuhan otot yang cepat sehingga berpengaruh terhadap turunnya persentase bobot otot. Bobot otot yang menurun pada meat bone ratio dapat disebabkan karena kandungan nutrisi dalam ransum belum mampu mencukupi kebutuhan itik secara optimal.

Berdasarkan data yang diperoleh dari penelitian ini, nilai rataan rasio otot-tulang pectoralis dari ketiga jenis itik lokal pada umur 6 bulan berada pada kisaran 5,1-5,8. Hal ini menunjukkan bahwa nilai rasio otot-tulang pectoralis pada penelitian ini lebih tinggi dibandingkan dengan hasil penelitian Matitaputty (2002), yang melaporkan bahwa persentase karkas itik Mandalung pada umur 10 minggu sebesar $55,14 \%$, sedangkan perbandingan otot dan tulang (meat bone ratio) pada bagian karkas khususnya pectoralis secara berurutan yakni sebesar 79,77 $\mathrm{g}$ : $20,23 \mathrm{~g}$, artinya hanya mencapai nilai 3,9 sehingga lebih kecil bila dibandingkan dengan kisaran yang diperoleh dari hasil penelitian ini. Hal ini mengindikasikan bahwa umur ternak juga dapat menjadi faktor yang berpengaruh terhadap bobot hidup yang tentunya akan berdampak terhadap bobot dan persentase bagian karkas yang dihasilkan.

\section{KESIMPULAN}

Berdasarkan hasil pengamatan, maka dapat disimpulkan bahwa perbedaan itik lokal tidak berpengaruh terhadap rasio otot-tulang pectoralis.

\section{UCAPAN TERIMAKASIH}

Terimakasih kepada laboratorium Biologi Struktur dan Fungsi Hewan Departemen Biologi UNDIP atas dana penelitian yang diberikan.

\section{DAFTAR PUSTAKA}

Amaludin, F., I. Suswoyo dan Roesdiyanto. 2013. Bobot dan Persentase Bagian-Bagian Karkas Itik Mojosari Afkir Berdasarkan Sistem dan 
Lokasi Pemeliharaan. Jurnal Ilmiah Peternakan 1(3): 924-932.

Arellano, H.A., Romero, S.F., and Tortoriello, M.A.C.J. 2004. Effectiveness and Tolerability of a Standardized Extract from Hibiscus sabdariffa in Patients with Mild to Moderate Hypertension: a Controlled and Randomized Clinical Trial. Phytomedicine 11: 375-382.

Armissaputri, N.K., Ismoyowati dan S. Mugiyono. 2013. Perbedaan Bobot dan Persentase Bagian-Bagian Karkas dan non Karkas pada Itik Lokal (Anas plathyrincos) dan Itik Manila (Cairina moschata). Jurnal Ilmiah Peternakan 1(3): 1086 -1094.

Buwono, F.A. 2007. Pengaruh Tingkat Protein Pakan dan Frekuensi Pemberian Pakan terhadap Kinerja Itik Mojosari (Anas Domesticus) Jantan Periode Awal. Skripsi. Universitas Brawijaya. Malang.

Damayanti, V. 2003. Studi Perbandingan Persentase Karkas, Bagian-Bagian Karkas dan Non Karkas pada Berbagai Unggas Lokal. Skripsi. Fakultas Peternakan. Universitas Jenderal Soedirman. Purwokerto.

Gultom, S.M., Supratman, R.D. H. dan Abun. 2014. Pengaruh Imbangan Energi-Protein Ransum Terhadap Bobot Karkas dan Bobot Lemak Abdominal Ayam Broiler Umur 3-5 Minggu. Skripsi. Fakultas Peternakan Universitas Padjajaran. Bandung.

Haroen, U. 2003. Respon Ayam Broiler yang Diberi Tepung Daun Sengon (Albizzia falcataria) dalam Ransum Terhadap Pertumbuhan dan Hasil Karkas. Jurnal Ilmiah Ilmu-ilmu Peternakan 6(1): 34-41.

Matitaputty, P.R. dan Suryana. 2010. Karakteristik Daging Itik dan Permasalahan Serta Upaya
Pencegahan Off-Flavor Akibat Oksidasi Lipida. Wartazoa 20(3).

Ningsih, S.W. 2004. Penampilan Produksi Kelinci Lokal Betina yang Diberi Rasio Hijauan dan Konsentrat Berbeda. Skripsi. Fakultas Peternakan. UGM. Yogyakarta.

Reksohadiprodjo, S. 1995. Pengantar Ilmu Peternakan Tropis. Badan Penerbitan Fakultas Ekonomi Universitas Gadjah Mada. Yogyakarta.

Samsudin, M., W. Sarengat dan H.N. Maulana. 2012. Pengaruh Perbedaan Lama Periode (Starter-Finisher) Pemberian Pakan dan Level Protein Terhadap Nisbah Daging Tulang dan Massa Protein Daging Dada dan Paha Ayam Pelung Umur 1-11 Minggu. Animal Agricultural Journal, 1 (1): 43-51.

Simamora, N. 2011. Performa Produksi dan Karakteristik Organ dalam Ayam Kampung Umur 12-16 Minggu yang Diinfeksi Cacing Ascaridia Galli dan Disuplementasi Ekstrak Daun Jarak Pagar (Jatropha Curcas Linn). Skripsi. Institut Pertanian Bogor. Bogor.

Soeparno. 2005. Ilmu dan Teknologi Daging. Edisi 4. Gadjah Mada University Press. Yogyakarta.

Standar Nasional Indonesia. 2009. Mutu Karkas dan Daging Ayam. SNI 3924:2009. Badan Standarisasi Nasional. Jakarta.

Suryanto, E. 1989. Pengaruh Perbedaan Pakan dan Umur Terhadap Persentase Karkas, Meat Bone Ratio (MBR) dan Organ-Organ Dalam Ayam Kampung. Buletin Peternakan. 13(1).

Widodo,W. 2005. Tanaman Beracun Dalam Kehidupan Ternak. UMM Press. Malang.

Windharyati, S. S. 2002. Beternak Itik Tanpa Air. Penebar Swadaya. Jakarta.

Yuwanta, T. 2004. Dasar Ternak Unggas. Kanisius. Yogyakarta. 